INTERACTION: Jurnal Pendidikan Bahasa: Vol. 5, No.1: Mei 2018

ISSN: 2406-9558; E-ISSN: 2406-9566

\title{
Improving Students' Ability in Classroom Interaction through Everyone Is the Teacher Here
}

\author{
Nunung Kuswanti \\ nunungkuswanti@gmail.com \\ STKIP Muhammadiyah Sorong
}

\begin{abstract}
This research is a case study that has been done in October until November 2013. The objective of this research was a group of students at seventh semester at Teacher Training and Education (STKIP) Muhammadiyah Sorong that was consists of five students. The aim of this research was to know whether 'Everyone is Teacher Here' is effective to improve students' ability in classroom interaction.The design of this research was time series design that is equivalent time series design. The data of this research was analyzed through SPSS program that is Wilcoxon Test (nonparametric statistic). The steps of this research were: 1) selecting the participant 2) Measure for the first time 3) Giving the intervention 4) Measure for the second time 5) Giving the intervention 6) Measure for the third time 7) Giving the intervention 8) Measure for the fourth time. The data had gotten then analyzed. Based on the result of data analysis had gotten Asymp. Sig. (2-tailed) 0,0195 for the first and the second test, 0,0205 for the second and the third test and 0,017 for the third and the fourth test in which $0,0195,0,0205$ and $0,017<0,05$, means that Ho was refused or Everyone is Teacher Here is effective to improve students' ability in classroom interaction. In overall also got the result of the first and the fourth test with Asymp. Sig. (2tailed) $=0,019<0,05$, means that Ho was refused.
\end{abstract}

\section{Key words: Everyone is Teacher Here}

\section{INTRODUCTION}

Human as the social creature of course will life among the other people with so many cultures. By the language we can express our ideas desires and feeling to others people. It means that language is the vital mean of communication.

Among the four language skills, speaking is one of the most important skill acquired by students not only for academic purposes but also to communicate and it is also become a demand for everyone who wants to participate in global scope of interaction. Mastery language is when we able to use it in communication.

In Indonesia, English is regarded as a foreign language. According to Kathleen M. Bailey (2003), an English teacher should be aware of the issues English as second 
language (ESL), and English as a Foreign Language (EFL) are have different setting in learning.The learners of English as a foreign language acquare the language to certain levels of profeciency.

In learning a language, there are four skills should be mastery by learners such as listening, reading, speaking and writing. All the skills are very important for a learner of language to mastery because actually there are relation between listening, reading, speaking and writing. As the teacher,we must be able to solve their problems aware of the important of speaking skill of language by finding out the enjoyable and suitable method in teaching and learning process that should be applied in order that they interested and more enthusiastic so that their regarding that English is difficult and worried in making some mistakes are not be the obstacles for them to keep their study and keep try on to speak in English. Further, teaching speaking skill means that we help the students in order that to be active and able to use the language.

Speaking is a complex skill requiring the simultaneous use of the number of different abilities. There are five components should be mastery by the students. They are pronunciation, grammar, vocabulary, fluency and comprehension. There are so many speaking activities can be applied in general. They are including discussions, speeches, role plays, conversations and so on. The role of speaking in improving the classroom interaction is very big. The interaction in the classroom can't be happened if one person and another didn't speak in the classroom. Classroom interaction is a sign or signal to whether the goal lesson is achieved or not. If the students are only silent and listen to their teacher explanation starting from the beginning until the ending of the lesson, we can say that the teacher is not really successful in teaching. It's because English is a communicative subject that supposed to be practiced both spoken and written.

The way of teacher to talk to students, and the manner in which they interact are important factors in both successful learning and teaching. Teaching and learning activity relating to academic activity will not run well if the students do not understand the instruction or the explanation. And it is related with the way how the teacher gives the instruction or giving explanation whether it is clear and using good sentences so that the students can receive it. We often find the students can not speak in English well in the school's enviroment or in the classroom although actually their teacher has given them the subject or material of speaking. It is because they rarely even never practice it in daily or because of their lack of opportunity to practice it.

Realize the background of the students in which they study in college of teacher training and education willing or not they must be able to teach the students, especially as an English teacher they must be able to speak English. Goes with the fact, the writer tries to find out the way to make the atmospherein learning speaking be exiting. The writer makes up her mind to use. Everyone is Teacher Here to help the students in improving their speaking ability. This method gives the opportunity to every students to take a role as a teacher for the other friends. Through this way hoped that the students 
INTERACTION: Jurnal Pendidikan Bahasa: Vol. 5, No.1: Mei 2018

ISSN: 2406-9558; E-ISSN: 2406-9566

can be active in speaking and able to teach in front of the class using the correct and clear language so that the students can understand the teacher instruction so that the classroom speech runs effectively.

\section{LITERATURE REVIEW}

\section{Previous of Study}

There are so many rwesearchers had done their research on speaking skill. The following are some studies had done in relation to improve students' speaking ability.

The study about speaking skill had done by I Ketut Astawa in (2011): "Improving students' speaking ability through sociodrama at the first grade of Madrasah Aliyah Muhammadiyah Aimas". He tried to solved this problem through sociodrama that he was sure that it is effective to improve their speaking. And based on the result of speaking test given in two cycles, he concluded that the use of sociodram could improve students' speaking ability at the first class of Madrasah Aliyah Muhammadiyah Aimas in the academic 2010/2011. This research the writer wanted to improve students speaking ability through Everyone is Teacher Here while his researched was through sociodrama.

Wika Dian Wijayanti (2011), had done her research in SMK Kristen 1 Surakarta with her focus research is implementation cooperative learning approach type Everyone is Teacher Here. This research was case study. The technique in collecting the data through unstructured interview, observation, documentation and test. According to the result of discussion, can be concluded that the implementation of Everyone is Teacher Here method can improve the learning result of accountant.

The research that had been done by Wika Dian Wijayanti had the same in the using of active learning strategy Everyone is Teacher Here and the kind of the research, that was a case study. While the aim of the research were different.

Reiska Fricelia (2013), has done her research with the purpose of the study was to improve students' achievement in learning history lesson by implement Everyone is Teacher Here that has done tenth grade of students at SMAN 10 Yogyakarta. The technical in collecting data in this research were observation, interview and documentation. Based on the test result, concluded that Everyone is Teacher Here can improve students' achievement in learning history lesson at tenth grade of students at SMAN 10 Yogyakarta, 2012/2013.

There was also a research that discussed about the influence of application of active learning strategies type Everyone is Teacher Here on students ability in comprehension mathematical concept that has done by Legi Novria Wulandari, Zulfaniti, and Dewi 
INTERACTION: Jurnal Pendidikan Bahasa: Vol. 5, No.1: Mei 2018

ISSN: 2406-9558; E-ISSN: 2406-9566

Yuliana Fitri at eighth grade of students at SMPN 1 Linggo Sari Baganti in 2013. In this study, the researchers concluded that the ability of comprehension mathematical concepts with the application of active learning strategies type Everyone is Teacher Here is better than the ability of comprehension mathematical concepts with the application of intentioned learning in class VIII SMPN 1 linggo Sari Baganti scholl year 2012/2013 with 95\% confidence level.

While the researches done by Reiska Fricelia, Legi Novria Wulandari, Zulfaniti, and Dewi Yuliana Fitri have the same as the writer in the use of active learning strategies type" Everyone is Teacher Here", but the purpose are different. Their focus study were to improve students' achievement in learning history lesson by implement Everyone is Teacher Here and students ability of comprehension mathematical concepts with the application of active learning strategies type Everyone is Teacher Here, while this study is focused on investigating how does everyone is teacher here improve students speaking ability.

\section{METHOD}

\section{Design}

The design at this research is time series design. There are two kinds of time series design, they are interupted time series design and equivalent time series design. In this research the writer used equivalent time series design, in which the investigator alternates alternates a treatment with a posttest measure. The data analysis then consists of comparing posttest measures or plotting them to discern pattern in the data over time

\section{Analysis Data}

The data of this research analyzed through time series analysis. This technique is commonly used in study of foreign language that to get the data only from a group. In case study, this technique is used to see the development of variable or phenomena in some period or to see the development a phenomenon in some period by seeing the mode (Bambang Setiyadi: 2006).

This design does require access to large participants and it requires only one group for the study. There are two important variations of this design, interrupted time series and equivalent time series design. The writer used the equivalent time series design in which will be analyzed through SPSS to if there is any increation or not after giving the intervention for a period.

\section{RESULT AND DISCUSSION}


INTERACTION: Jurnal Pendidikan Bahasa: Vol. 5, No.1: Mei 2018

ISSN: 2406-9558; E-ISSN: 2406-9566

\section{Data Presentation}

After doing the first, second, third, and four tests the writer got the data to be analyzed. The data was gotten through speaking test before getting the treatment and after getting the treatment. The data has placed in table as follow (the name of students just using initial):

Table 4. The Result of the First Test before Giving the Intervention

\begin{tabular}{|c|c|c|c|c|c|c|c|}
\hline No & $\begin{array}{c}\text { Name of } \\
\text { Students }\end{array}$ & Pronunciation & Grammar & Vocabulary & Fluency & $\begin{array}{c}\text { Total } \\
\text { Score }\end{array}$ & Value \\
\hline 1 & Student A & 2 & 1 & 1 & 2 & 6 & 30 \\
\hline 2 & Student B & 1 & 1 & 1 & 1 & 4 & 20 \\
\hline 3 & Student C & 2 & 1 & 1 & 2 & 6 & 30 \\
\hline 4 & Student D & 1 & 1 & 2 & 2 & 6 & 30 \\
\hline 5 & Student E & 2 & 1 & 2 & 2 & 7 & 35 \\
\hline \multicolumn{3}{|c|}{} \\
\hline
\end{tabular}

The data in the table above (table 4) is the data result of the first test in which they had not got any intervention before. Based on the data in the table above (table 3), it shows that the students speaking ability in the context of classroom interaction before giving the intervention 'Everyone is Teacher Here' was bad, their pronunciation was very hard to understand, the mistakes in grammar and word order errors made their conversation was difficult, misuse of word and vey limited vocabulary made conversation was quite difficult and the fluency is usually hesitant and often forced into silence by language limitation.

Table V. The Result of the Second test (T2), after Giving the Intervention after the First Test

\begin{tabular}{|c|c|c|c|c|c|c|c|}
\hline No & $\begin{array}{c}\text { Name of } \\
\text { Students }\end{array}$ & Pronunciation & Grammar & Vocabulary & Fluency & $\begin{array}{c}\text { Total } \\
\text { Score }\end{array}$ & Value \\
\hline 1 & Student A & 2 & 2 & 2 & 2 & 8 & 40 \\
\hline 2 & Student B & 2 & 2 & 1 & 1 & 6 & 30 \\
\hline 3 & Student C & 2 & 2 & 2 & 2 & 8 & 40 \\
\hline 4 & Student D & 1 & 2 & 2 & 2 & 7 & 35 \\
\hline 5 & Student E & 3 & 2 & 3 & 2 & 10 & 50 \\
\hline \multicolumn{8}{|c|}{ Average $=$} \\
\hline
\end{tabular}

The table above describes the students' speaking ability after giving the intervention for a period (six times meeting). The result shows that they got the average value thirty nine (39). It shows that their ability was not far different from the first test. Although 
they were still hard in pronunciation, grammar, vocabulary and fluency but it was not so hard as the first time before getting the intervention.

Table VI. The Result of the Thrid test (T3), after Giving the Intervention after the Second Test

\begin{tabular}{|c|l|c|c|c|c|c|c|}
\hline No & $\begin{array}{c}\text { Name of } \\
\text { Students }\end{array}$ & Pronunciation & Grammar & Vocabulary & Fluency & $\begin{array}{c}\text { Total } \\
\text { Score }\end{array}$ & Value \\
\hline 1 & Student A & 3 & 3 & 3 & 2 & 11 & 55 \\
\hline 2 & Student B & 2 & 3 & 3 & 2 & 10 & 50 \\
\hline 3 & Student C & 3 & 3 & 3 & 2 & 10 & 50 \\
\hline 4 & Student D & 3 & 2 & 2 & 2 & 10 & 50 \\
\hline 5 & Student E & 3 & 3 & 4 & 3 & 13 & 65 \\
\hline \multicolumn{7}{|r|r|r|}{} \\
\hline
\end{tabular}

After the second test they were given the intervention again for a period it was about six times meeting. Their average value for this test was fifty four (54). What they had gotten was include in a good criteria, it is better than before. They got any change.

The pronunciation problem necessities unstructured listening and occasionally lead to misunderstanding. They still made frequent errors of grammar and word-order and frequently used the wrong words, the speed and fluency were rather strongly affected by language problem.

Table VII. The Result of the Fourth Test (T4), after Giving the intervention after the Third Test

\begin{tabular}{|c|l|c|c|c|c|c|c|}
\hline No & $\begin{array}{c}\text { Name of } \\
\text { Students }\end{array}$ & Pronunciation & Grammar & Vocabulary & Fluency & $\begin{array}{c}\text { Total } \\
\text { Score }\end{array}$ & Value \\
\hline 1 & Student A & 4 & 3 & 4 & 3 & 14 & 70 \\
\hline 2 & Student B & 3 & 3 & 3 & 3 & 12 & 60 \\
\hline 3 & Student C & 3 & 4 & 3 & 3 & 13 & 65 \\
\hline 4 & Student D & 4 & 3 & 3 & 3 & 14 & 65 \\
\hline 5 & Student E & 4 & 4 & 4 & 4 & 16 & 80 \\
\hline
\end{tabular}


INTERACTION: Jurnal Pendidikan Bahasa: Vol. 5, No.1: Mei 2018

ISSN: 2406-9558; E-ISSN: 2406-9566

Average $=68$

The table above describes the result of their test in which the average value is sixty eight (68) with the lowest and the highest score were sixty and eighty (60 and 80). The result of this test shows that there is any increasing on their speaking ability then include in very good criteria. Their pronunciation was intelligible, though one is conscious of a definite accent, they occasionally make grammatical or word-order errors, sometimes uses inappropriate and must rephrase ideas because of lexical inadequacies, the speed of speech seemed to be slightly affected by language problem.

\section{Analysis the Data}

The aim of this analysis is to see if there is any improvement on the students speaking ability in the context on classroom speeech since the first test before given the intervention until the fourth test after giving the intervention. In which the writer would like to see the result of the test by comparing the result of:

1. The first test and the second test.

2. The second and the third test.

3. The third test and the fourth test, and in overall

4. The first and the fourth test.

The confidence interval as the default, this SPSS using the confidence interval $95 \%$ or the significant was $100 \%-95 \%=5 \%$. The procedure in analyzing the data through SPSS are as the follow:

1. Open the program of SPSS then click the vaiable view, then type before and after in the first and the second coulomb.

2. Click the data view, then insert the data in coloumb 'before' and 'after'.

3. Choose analyzed, then choose nonparametric test, click 2 pared samples, then click before to insert the data 'before' and click after to insert the data 'after' then click Ok. 
INTERACTION: Jurnal Pendidikan Bahasa: Vol. 5, No.1: Mei 2018

ISSN: 2406-9558; E-ISSN: 2406-9566

Table VIII. The Result of Test 1-2

Wilcoxon Signed Ranks Test

Ranks

\begin{tabular}{|c|l|c|c|c|}
\hline & & $\mathrm{N}$ & Mean Rank & Sum of Ranks \\
\hline \multirow{3}{*}{ Before - After } & Negative & $0^{\mathrm{a}}$ & .00 & .00 \\
Ranks & $\begin{array}{l}\text { Positive } \\
\text { Ponks }\end{array}$ & $5 \mathrm{~b}$ & 3.00 & 15.00 \\
& $\begin{array}{l}\text { Ra } \\
\text { Ties }\end{array}$ & & \\
& Total & 5 & & \\
\hline
\end{tabular}

a. After $<$ Before

b. After $>$ Before

c. After $=$ Before

Test Statistics ${ }^{b}$

\begin{tabular}{|l|c|}
\hline & After - Before \\
\hline$Z$ & $-2.060-^{\mathrm{a}}$ \\
Asymp. Sig. (2-tailed) & .039 \\
\hline
\end{tabular}

a. Based on negative ranks.

b. Wilcoxon Signed Ranks Test

Based on the data analysis above, the writer took the decision based on the probability with the basis in taking the decision:

If the probability $>0,05$, it means that Ho is received If the probability $<0,05$, it means that Ho is rejected

The decision:

On the table above shows the asymp. Sig. (2-tailed)/asymptotic significance for the test of two side is 0,039 . Because the case is the test of one side, so the probability become $0,039 / 2=0,0195$. So, has gotten the probability was smaller than $\alpha(0,0195<0,05)$, means that Ho was rejected. 
INTERACTION: Jurnal Pendidikan Bahasa: Vol. 5, No.1: Mei 2018

ISSN: 2406-9558; E-ISSN: 2406-9566

Table IX. The Result of Test 2-3

Wilcoxon Signed Ranks Test

Ranks

\begin{tabular}{|ll|c|c|c|}
\hline & & $\mathrm{N}$ & Mean Rank & $\begin{array}{c}\text { Sum of } \\
\text { Ranks }\end{array}$ \\
\hline After - Before & Negative Ranks & $0^{\mathrm{a}}$ & .00 & .00 \\
& Positive Ranks & $5^{\mathrm{b}}$ & 3.00 & 15.00 \\
& Ties & $0^{\mathrm{c}}$ & & \\
& Total & 5 & & \\
\hline
\end{tabular}

a. After $<$ Before

b. After > Before

c. After $=$ Before

Test Statistics ${ }^{b}$

\begin{tabular}{|c|c|}
\hline & \\
& After - Before \\
\hline Z & $-2.041^{\mathrm{a}}$ \\
Asymp. Sig. (2-tailed) & .041 \\
\hline
\end{tabular}

a. Based on negative ranks.

b. Wilcoxon Signed Ranks Test

The table above is the result of data analysis through SPSS. On the table above shows the asymp. Sig. (2-tailed)/asymptotic significance for the test of two side is 0,041 . Because the case is the test of one side, so the probability become $0,041 / 2=0,0205$. So, has gotten the probability was smaller than $\alpha(0$, $041<0,05)$, means that Ho was rejected. 
INTERACTION: Jurnal Pendidikan Bahasa: Vol. 5, No.1: Mei 2018

ISSN: 2406-9558; E-ISSN: 2406-9566

Table X. The Result of Test 3-4

Wilcoxon Signed Ranks Test

Ranks

\begin{tabular}{|lc|c|c|c|}
\hline & & $\mathrm{N}$ & Mean Rank & Sum of Ranks \\
\hline $\begin{array}{l}\text { After } \\
\text { Before }\end{array}$ & - Negative Ranks & $0^{\mathrm{a}}$ & .00 & .00 \\
& Positive Ranks & $5^{\mathrm{b}}$ & 3.00 & 15.00 \\
& Ties & $0^{\mathrm{c}}$ & & \\
& Total & 5 & & \\
& & & & \\
\hline
\end{tabular}
a. After $<$ Before
b. After $>$ Before
c. After $=$ Before

Test Statistics $^{b}$

\begin{tabular}{|c|c|}
\hline & \\
& After- Before \\
\hline $\mathrm{Z}$ & \\
Asymp. Sig. (2-tailed) & $-2.121^{\mathrm{a}^{\mathrm{a}}}$ \\
\hline
\end{tabular}

a. Based on negative ranks.

\section{b. Wilcoxon Signed Ranks Test}

On the table above shows the asymp. Sig. (2-tailed)/asymptotic significance for the test of two side is 0,034 . Because the case is the test of one side, so the probability become $0,034 / 2=0,017$. So, has gotten the probability was smaller than $\alpha(0,041<0,05)$, means that Ho was rejected.

\section{Data Interpretation}

Based on the data analysis above shows that there is any improvement on students speaking ability since the first until the fourth test in which the probability $<0,05$ that means that Ho is refused and $\mathrm{H} 1$ is received. So, Everyone is Teacher Here is 
effective to improve students' speaking ability. The table bellow describes briefly the result of the data analysis since the first until the fourth test.

Table XI. The Result of the First-Third Test

$\begin{array}{ccccc}\text { No } & \text { Test } & \text { Probability } & \text { Explanation } & \text { Decision } \\ 1 & 1-2 & 0,0195 & 0,0195<0,05 & \text { Ho is rejected } \\ 2 & 2-3 & 0,0205 & 0,0205<0,05 & \text { Ho is rejected } \\ 3 & 3-4 & 0,017 & 0,017<0,05 & \text { Ho is rejected }\end{array}$

In overall, can be seen the result since the first until the fourth test as follow.

Table XII .The Result Test 1-4

Ranks
\begin{tabular}{|l|l|c|c|c|}
\hline & & & & \\
& & $\mathrm{N}$ & Mean Rank & Sum of Ranks \\
\hline After - Before & Negative Ranks & $0^{\mathrm{a}}$ & .00 & .00 \\
& Positive Ranks & $5^{\mathrm{b}}$ & 3.00 & 15.00 \\
& Ties & $0^{\mathrm{c}}$ & & \\
& Total & 5 & & \\
\hline
\end{tabular}
a. After $<$ Before
b. After $>$ Before
c. After $=$ Before

Test Statistics $^{\mathbf{b}}$

\begin{tabular}{|c|c|}
\hline & After - Before \\
\hline $\mathrm{Z}$ & $-2.070-^{\mathrm{a}}$ \\
Asymp. Sig. (2-tailed) & .038 \\
\hline
\end{tabular}

a. Based on negative ranks.

b. Wilcoxon Signed Ranks Test 
INTERACTION: Jurnal Pendidikan Bahasa: Vol. 5, No.1: Mei 2018

ISSN: 2406-9558; E-ISSN: 2406-9566

The result of data analysis above had gotten Asymp. Sig. (2-tailed) =0,038/2 =0,019

$<0,05$, means that there is any improvement after giving the intervention (Everyone is Teacher Here).

\section{DISCUSSION}

Many factors influence the students missing their self-confidence and make them unable to speak. After doing an observation and casual conversation the writer found some factors make the students feel afraid to speak, such as:

a. Because the teacher shows the angry face and show not good responses when they do some mistakes, so that the next they feel afraid in making mistakes when they were asked to speak and silent is the last choice.

b. The other students laugh them for making mistakes that make them missing the mental.

Everyone is Teacher Here is a good strategy provide the chances for the students to be an active and confident student. Through this method were taught to always give respect to the other and not laugh them when they make some mistakes. And to give respect whatever their ideas or question. It is related with one of the principle of Contextual Teaching and Learning that is differentiation principle.

The differentiation be real when Contextual Teaching and Learning challenge the students to give respect the other unique, to give respect the differences, to become a creative student, to work together to get the new and different ideas and to realize that differential is the strength and settled.

In overall can see since the first they came to study. They always say sorry and shy then said that they really cannot speak English. They usually get some bad response from the teacher such as the teacher says 'stupid' or another kinds of expression that shows the bad or careless face, and the laughing of the other friends that make them be not confidence and really afraid to make a mistake. Lately silent is the best choice.

The writer then gave them the intervention 'Everyone is Teacher Here'. They began to be active and tried to be brave to practice without thinking to be shame in making a mistake. They always ask what they had not understand and more active to find out what they had not understand by sharing with the other friends.

Based on the result of speaking test were given since the first until the fourth test, there always get the improvement, as shown in the table bellow :

\begin{tabular}{|c|c|c|c|c|}
\hline No & Test & Probability & Explanation & Decision \\
\hline
\end{tabular}


INTERACTION: Jurnal Pendidikan Bahasa: Vol. 5, No.1: Mei 2018

ISSN: 2406-9558; E-ISSN: 2406-9566

\begin{tabular}{|c|c|c|c|c|}
\hline 1 & $1-2$ & 0,0195 & Ho is refused \\
\hline 2 & $2-3$ & 0,0205 & & Ho is refused \\
\hline 3 & $3-4$ & 0,017 & & Ho is refused \\
\hline
\end{tabular}

It could be concluded that the use of Everyone is Teacher Here is effective to improve students' speaking ability in the context of classroom speech at a group of students at STKIP Muhammadiyah Sorong in academic years 2012.

\section{REFERENCES}

AhmadNoer, 2004. Statistik Deskriptive dan Probabilita. Yogyakarta: BPFEYogyakarta.

Bambang Setiyadi, 2006. Metode Penelitian untuk Pengajaran Bahasa Asing. Yogyakarta: Graha Ilmu.

David P. Haris, 1996. Testing English as a Second Language. United Stated America: McGraw-Hill Book Company.

I Ketut Astawa, 2011. Improving students' speaking ability through sociodrama. Madrasal Aliyah Muhammadiyah Aimas

John M. Echols, Hasan Shadily,. Kamus Inggris Indonesia. PT. GRAMEDIA JAKARTA.

John W. Cresswell, 2008. Educational Research: Planning, conducting and evaluating quantitative and qualitative research. Merril Prentice Hall. Pearson International third edition

Legi Novria Wulandari., Zulfaniti., Dewi Yulianti Fitri., 2013. The implement of application of active learning strategies type Everyone is Teacher Here on student's ability in comprehension mathematical concept. SMP N 1 Linggo Sara Baganti.

Reiska Fricelia, 2013. Improve students' achievement in learning history lesson by implement Everyone is Teacher Here. SMKN 10 Yogyakarta.

Wika Dian Wijayanti, 2011. Implementation cooperative learning approach type Everyone is Teacher Here. SMK Kristen 1 Surakarta. 